J. Dairy Sci. 90:2309-2314

doi:10.3168/jds.2006-713

(c) American Dairy Science Association, 2007.

\title{
The Effect of Lactobacillus buchneri 40788 on the Fermentation and Aerobic Stability of Ground and Whole High-Moisture Corn ${ }^{1}$
}

\author{
L. Kung, Jr., ${ }^{2}$ R. J. Schmidt, T. E. Ebling, and W. Hu \\ Department of Animal and Food Sciences, University of Delaware, Newark 19716-2150
}

\section{ABSTRACT}

Experiments were conducted to evaluate the effects of inoculating high-moisture corn (HMC) with Lactobacillus buchneri 40788 on silage fermentation and aerobic stability. In the first experiment, HMC (73\% DM) was ground and treated with nothing, L. buchneri 40788 to achieve $6.6 \times 10^{5} \mathrm{cfu} / \mathrm{g}$ of HMC (LB), a mixture of enzymes (ENZ), LB + ENZ, or $0.1 \%$ (wet weight basis) of a liquid mold inhibitor and was ensiled in 20$\mathrm{L}$ bucket silos for $90 \mathrm{~d}$. Treatments with LB and LB + ENZ increased the concentrations of acetic acid and improved the aerobic stability of ground HMC relative to other treatments. Treatment ENZ had no effect on the chemical composition or aerobic stability of ground HMC. The only effect of the liquid mold inhibitor relative to untreated HMC was that it increased the concentration of propionic acid, but this did not improve its aerobic stability. In a second experiment, HMC (75\% DM) was harvested as the intact, whole grain and treated with nothing, L. buchneri 40788 to achieve $4 \times 10^{5} \mathrm{cfu} / \mathrm{g}$ of HMC, L. buchneri 40788 to achieve 6 $\times 10^{5} \mathrm{cfu} / \mathrm{g}$ of HMC, or L. buchneri 40788 to achieve 8 $\times 10^{5} \mathrm{cfu} / \mathrm{g}$ of HMC and ensiled for $120 \mathrm{~d}$. Treatments with L. buchneri 40788 resulted in whole HMC with lower concentrations of water-soluble carbohydrates; higher concentrations of lactic, acetic, and propionic acids; and greater numbers of lactic acid bacteria but fewer molds when compared with untreated corn. As a group, inoculated silages were more aerobically stable than untreated silage, but increasing levels of application did not further improve the response. These experiments showed that addition of $L$. buchneri 40788 , but not addition of an enzyme mixture or a liquid mold inhibitor, improved the aerobic stability of ground and whole HMC harvested between 73 and $75 \%$ DM.

Key words: Lactobacillus buchneri, high-moisture corn, silage

Received October 27, 2006.

Accepted December 30, 2006.

${ }^{1}$ Partially supported by Lallemand Animal Nutrition, Milwaukee, WI.

${ }^{2}$ Corresponding author: lksilage@udel.edu

\section{INTRODUCTION}

High-moisture corn (HMC) is often prone to aerobic deterioration when it is exposed to air, and several factors are responsible for this finding. First, fermentation is often restricted because of its relatively low moisture (compared with most forage crops) and fermentable sugar contents. Thus, the accumulation of total acids produced is quite low in HMC. Second, the concentration of starch is high in this crop, and starch can be used as a source of energy for yeasts. Under anaerobic conditions, yeasts can ferment starch to ethanol, but when air is present, many yeasts are able to assimilate lactic acid, which initiates spoilage in many types of silages (Woolford, 1990).

Spoiled HMC is a concern because the net loss in nutritive value can negatively affect animal performance (Hoffman and Ocker, 1997). Thus, antifungal compounds have been added to HMC to improve its aerobic stability. Additives containing propionic acid and ammonia have been used with varied success (Britt and Huber, 1975; Sebastian et al., 1996). The primary reasons why they are not more widely used include the high cost and less than desirable handling characteristics. An alternative to the application of chemicals to improve aerobic stability is to inoculate feeds with microorganisms to alter the fermentation process to improve stability. Although the addition of homolactic acid bacteria has improved the aerobic stability of HMC in some studies (Phillip and Fellner, 1992), it has not always been effective (Wardynski et al., 1993), most likely because lactic acid and a low $\mathrm{pH}$ do not effectively curb the growth of yeasts. A more targeted approach with microbes has been the use of bacteria that specifically produce antifungal compounds during ensiling. For example, Dawson et al. (1998) reported improved aerobic stability in HMC treated with Propionibacteria acidilactici. However, the use of this bacterium and similar organisms has not been widespread because they are acid intolerant and very slow growing. Lactobacillus buchneri has also improved the aerobic stability of HMC. It is a heterolactic lactobacillus that anaerobically degrades moderate amounts of lactic acid to acetic acid (Oude Elferink 
Table 1. Chemical (DM basis) and microbial composition (wet basis) of high-moisture corn at harvest for experiments 1 and 2

\begin{tabular}{lcc}
\hline Item & Experiment 1 & Experiment 2 \\
\hline DM, \% & 73.17 & 75.02 \\
Lactic acid bacteria, $\log _{10} \mathrm{cfu} / \mathrm{g}$ & $\mathrm{ND}^{1}$ & 4.64 \\
Yeasts, $\log _{10} \mathrm{cfu} / \mathrm{g}$ & 4.81 & 3.52 \\
$\mathrm{Molds}, \log _{10} \mathrm{cfu} / \mathrm{g}$ & 4.36 & 3.34 \\
$\mathrm{pH}$ & 5.80 & 5.45 \\
$\mathrm{NDF}, \%$ & 7.92 & 9.63 \\
$\mathrm{ADF}, \%$ & 2.55 & 3.33 \\
$\mathrm{CP}, \%$ & 9.95 & 9.64 \\
$\mathrm{NH}_{3}$-N, \% & 0.008 & 0.008 \\
Water-soluble carbohydrates, \% & 1.35 & 0.52 \\
\hline
\end{tabular}

${ }^{1} \mathrm{ND}=$ not determined.

et al., 2001). Although L. buchneri is naturally found on some plant materials, Hesser et al. (1967) reported that it represented only $3 \%$ of the lactobacilli isolates on HMC. Torriani et al. (1992) could not isolate $L$. buchneri from corn silage even though it was over $20 \%$ of the isolates in alfalfa. Because L. buchneri is not found in high levels on most forage crops, isolates have been identified and developed into silage inoculants (Muck, 1996). A significant body of evidence is available showing that inoculation with $L$. buchneri improves the aerobic stability of silages (Kleinschmit and Kung, 2006). However, only a few studies have been conducted with its addition to HMC (Kendall et al., 2002; Taylor and Kung, 2002), and to our knowledge, no studies have evaluated its effectiveness with and without additional enzymes or evaluated its effectiveness based on the form of storage (ground and whole shelled). Thus, the objective of experiment 1 was to determine the effect of $L$. buchneri 40788 , enzymes, or a combination of L. buchneri 40788 and enzymes on the fermentation and aerobic stability of ground HMC. A liquid mold inhibitor containing buffered propionic acid and other antifungal agents was used as a positive control. The objective of experiment 2 was to determine the effectiveness on improving aerobic stability of adding various levels of $L$. buchneri 40788 to whole HMC.

\section{MATERIALS AND METHODS}

In experiment 1, HMC (Table 1) was harvested (73\% DM) and ground, and was either untreated or treated with 1) L. buchneri 40788 (Lallemand Animal Nutrition, Milwaukee, WI) to achieve $6.6 \times 10^{5} \mathrm{cfu} / \mathrm{g}$ of HMC $(\mathbf{L B}), 2)$ a mixture of enzymes [ $\beta$-glucanase (EC 3.2 .1 .78 ) to achieve $11.5 \mathrm{mg}$ of glucose liberated $/ \mathrm{min}$ per $\mathrm{kg}$ of feed, $\alpha$-amylase (EC 3.2.1.1) to achieve 5.77 $\mathrm{mg}$ of glucose liberated/min per $\mathrm{kg}$ of feed, and xylanase (EC 3.2.1.8) to achieve $6.26 \mathrm{mg}$ of xylose liberated/ min per kg of feed, Lallemand Animal Nutrition, Mil- waukee, WI; ENZ], 3) a combination of LB + ENZ, or 4) $0.1 \%$ (wet weight basis) of a liquid mold inhibitor (Ultra Curb, $82 \%$ acid content composed of propionic acid, acetic acid, sodium hydroxide, ammonium hydroxide, benzoic acid, sorbic acid, methylparaben, and propylparaben, Kemin Americas, Inc., Des Moines, IA; LMI). The microbial inoculant and enzyme mixture were mixed in deionized water and applied with a hand sprayer at a rate of $500 \mathrm{~mL} / 75 \mathrm{~kg}$ of fresh corn. The liquid mold inhibitor was also applied to the corn with a hand sprayer. Three $20-\mathrm{L}$ macro silos $(27 \mathrm{~cm}$ width $\times 36 \mathrm{~cm}$ height) were prepared for each treatment, stored between 20 and $26^{\circ} \mathrm{C}$, and opened after $90 \mathrm{~d}$ of ensiling. Corn (fresh and ensiled) was analyzed for DM, water-soluble carbohydrates (WSC), $\mathrm{pH}$, yeasts, molds, $\mathrm{NH}_{3}-\mathrm{N}, \mathrm{ADF}, \mathrm{NDF}, \mathrm{CP}$, lactic acid, VFA, and ethanol. All analyses were as described by Kung and Ranjit (2001). Aerobic stability was determined on silages by placing $3-\mathrm{kg}$ of corn into insulated buckets, with a thermocouple wire placed in the geometric center of the mass. The wire was attached to a data logger that recorded temperatures every 5 min. Buckets were placed in a room with a constant temperature of $25 \pm$ $1^{\circ} \mathrm{C}$, and aerobic stability was defined as the length of time required for the temperature of the HMC to increase in temperature $2^{\circ} \mathrm{C}$ above the baseline after exposure to air.

In experiment 2, HMC (Table 1) was harvested (75\% of DM) as the whole grain (without grinding) and left untreated or was treated with 1) L. buchneri 40788 to achieve $4 \times 10^{5} \mathrm{cfu} / \mathrm{g}$ of HMC (LB400), 2) L. buchneri 40788 to achieve $6 \times 10^{5} \mathrm{cfu} / \mathrm{g}$ of HMC (LB600), or 3) L. buchneri 40788 to achieve $8 \times 10^{5} \mathrm{cfu} / \mathrm{g}$ of HMC (LB800). All methods were as previously described, with the exception that 4 replicate silos were made for each treatment and the material was ensiled for 120 d prior to opening. In addition, HMC was analyzed for numbers of lactic acid bacteria (LAB). For the enumeration of LAB, serial dilutions of water extracts were made in sterile Ringer's solution. Samples were pourplated in de Man, Rogosa, and Sharpe agar (Oxoid CM361, Unipath, Basingstoke, UK). Agar plates were incubated aerobically at $32^{\circ} \mathrm{C}$ for $48 \mathrm{~h}$ before enumeration of colonies.

Microbial data were transformed and reported as $\log _{10} / \mathrm{g}$ of wet HMC. All data were analyzed by ANOVA using the GLM procedures of SAS (SAS Institute, 1999). Tukey's test (Snedecor and Cochran, 1980) was used to test treatment means $(P<0.05)$ for experiment 1 . In experiment 2 , least squares means are reported because of some missing data. Contrasts were constructed, and the single degree-of-freedom orthogonal comparisons were 1) untreated vs. L. buchneri addition, 2) linear effect of $L$. buchneri addition, and 3) 
Table 2. The effect of microbial, enzyme, and chemical additives on the fermentation end-products (DM basis) and microbial populations (wet weight basis) of ground high-moisture corn after $90 \mathrm{~d}$ of storage (experiment 1)

\begin{tabular}{lcccccc}
\hline & \multicolumn{5}{c}{ Treatment $^{1}$} \\
\cline { 2 - 6 } Item & Control & LB & ENZ & LB + ENZ & LMI & SEM \\
\hline DM recovery, \% & 95.9 & 96.2 & 96.9 & 95.3 & 97.2 & 0.3 \\
DM, \% & $71.5^{\mathrm{a}}$ & $71.2^{\mathrm{c}}$ & $71.4^{\mathrm{ab}}$ & $71.2^{\mathrm{bc}}$ & $71.7^{\mathrm{a}}$ & $<0.01$ \\
$\mathrm{CP} \%$ & 10.17 & 10.04 & 10.08 & 9.95 & 9.95 & 0.07 \\
$\mathrm{NH}$-N, \% & $0.021^{\mathrm{b}}$ & $0.032^{\mathrm{a}}$ & $0.026^{\mathrm{ab}}$ & $0.032^{\mathrm{a}}$ & $0.023^{\mathrm{b}}$ & 0.002 \\
$\mathrm{ADF}, \%$ & 2.32 & 2.32 & 2.08 & 2.26 & 2.28 & 0.15 \\
NDF, \% & 8.36 & 8.29 & 8.44 & 7.72 & 7.92 & 0.41 \\
Water-soluble carbohydrates, \% & $<0.10$ & $<0.10$ & $<0.10$ & $<0.10$ & 0.40 & 0.10 \\
pH & $4.01^{\mathrm{b}}$ & $4.23^{\mathrm{a}}$ & $4.03^{\mathrm{b}}$ & $4.25^{\mathrm{a}}$ & $3.97^{\mathrm{b}}$ & 0.01 \\
Lactic acid, \% & $0.73^{\mathrm{bc}}$ & $0.60^{\mathrm{bc}}$ & $0.80^{\mathrm{b}}$ & $0.52^{\mathrm{c}}$ & $1.26^{\mathrm{a}}$ & 0.05 \\
Acetic acid, \% & $0.23^{\mathrm{c}}$ & $0.71^{\mathrm{a}}$ & $0.36^{\mathrm{b}}$ & $0.70^{\mathrm{a}}$ & $0.24^{\mathrm{c}}$ & 0.02 \\
Propionic acid, \% & $<0.01^{\mathrm{b}}$ & $<0.01^{\mathrm{b}}$ & $<0.01^{\mathrm{b}}$ & $<0.01^{\mathrm{b}}$ & $0.04^{\mathrm{a}}$ & $<0.01$ \\
Ethanol, \% & 0.36 & 0.52 & 0.31 & 0.44 & 0.26 & 0.06 \\
Molds, log cfu/g & 5.09 & 5.47 & 5.88 & 5.03 & 4.93 & 0.27 \\
Yeasts, log cfu/g & $4.52^{\mathrm{b}}$ & $5.38^{\mathrm{ab}}$ & $5.91^{\mathrm{a}}$ & $4.66^{\mathrm{b}}$ & $4.69^{\mathrm{b}}$ & 0.27 \\
\hline
\end{tabular}

${ }^{\mathrm{a}-\mathrm{c}}$ Means in rows with unlike superscripts differ, $P<0.05$.

${ }^{1}$ Control $=$ untreated; $\mathrm{LB}=$ Lactobacillus buchneri 40788 added to achieve a final application rate of 6.6 $\times 10^{5} \mathrm{cfu} / \mathrm{g}$ of wet high-moisure corn; $\mathrm{ENZ}=\mathrm{a}$ mixture of enzymes; LB $+\mathrm{ENZ}=$ L. buchneri 40788 and a mixture of enzymes; LMI $=$ a liquid mold inhibitor $(0.1 \%$ wet weight basis $)$.

quadratic effect of $L$. buchneri addition. Significance was defined as $P \leq 0.05$, whereas $0.05<P \leq 0.10$ was considered to indicate a trend toward a significant effect.

\section{RESULTS AND DISCUSSION}

The chemical and microbiological data from ground HMC in experiment 1 after $90 \mathrm{~d}$ of storage is shown in Table 2. The DM recovery was not different among the treatments (range 95.3 to 97.2\%). Small (but not biologically significant) differences were found in the DM content (range 71.2 to $71.7 \%$ ) of the treatments. No differences were detected among treatment means for the final concentrations of CP, ADF, NDF, or WSC. In a meta-analysis of published research on $L$. buchneri, Kleinschmit and Kung (2006) reported that inoculation did not affect the concentrations of $\mathrm{CP}, \mathrm{NDF}$, or $\mathrm{ADF}$ of ensiled forage crops. However, they did report that inoculation resulted in a trend for lower concentrations of WSC. Treatments LB and LB + ENZ had greater concentrations of $\mathrm{NH}_{3}-\mathrm{N}(0.032 \%$ for both, $P<0.05)$ than did other treatments $(0.021$ to $0.026 \%)$, but the differences were small. Similar findings were not observed in a previous study with HMC (Taylor and Kung, 2002) or in other studies with corn silages or grass and small-grain silages (Kleinschmit and Kung, 2006). The terminal $\mathrm{pH}$ of ground HMC treated with LB (4.23) and LB + ENZ (4.25) was higher $(P<0.05)$ than for untreated HMC (4.01), ENZ (4.03), and LMI (3.97). A moderately higher $\mathrm{pH}$ in silages treated with L. buchneri is a common finding (Kleinschmit and
Kung, 2006) because of the conversion of lactic to acetic acid (Oude Elferink et al., 2001). Although not statistically different, LB $(0.60 \%)$ and LB + ENZ $(0.52 \%)$ had numerically lower concentrations of lactic acid when compared with untreated corn $(0.73 \%)$. Treatment ENZ had no effect on the concentration of lactic acid, but treatment with LMI increased its concentration $(1.26 \%)$. Treatment with buffered propionic acid-based additives has resulted in increased concentrations of lactic acid in some studies (Kung et al., 2000; Kung and Ranjit, 2001) but not in others (Taylor and Kung, 2002). As expected, the concentration of acetic acid was greater $(P<0.05)$ for LB $(0.71 \%)$ and LB + ENZ $(0.70 \%)$ when compared with untreated corn $(0.23 \%)$ and LMI $(0.24 \%)$. Treatment ENZ increased the concentration of acetic acid $(0.36 \%)$ relative to no treatment, but the magnitude of response was less than for LB. Treatment LMI had more propionic acid $(0.04 \%$, $P<0.05$ ) than did other treatments because this acid was a major ingredient in the formulation. Treatments had no effect on the concentration of ethanol. Inoculation with LB and LB + ENZ did not affect the numbers of yeasts and molds in ground HMC when compared with untreated corn. Treatment with ENZ alone (5.91 $\log \mathrm{cfu} / \mathrm{g}$ ) had more yeasts than did untreated corn (4.52 log cfu/g), LB + ENZ (4.66 log cfu/g), and LMI (4.69 log cfu/g). Mixtures of enzymes have been added to forages at ensiling to release more WSC for use during the ensuing fermentation. Although adding enzymes with fibrolytic activities to HMC would be theoretically questionable, the mixture of enzymes that we added also contained amylase activity. However, it is 


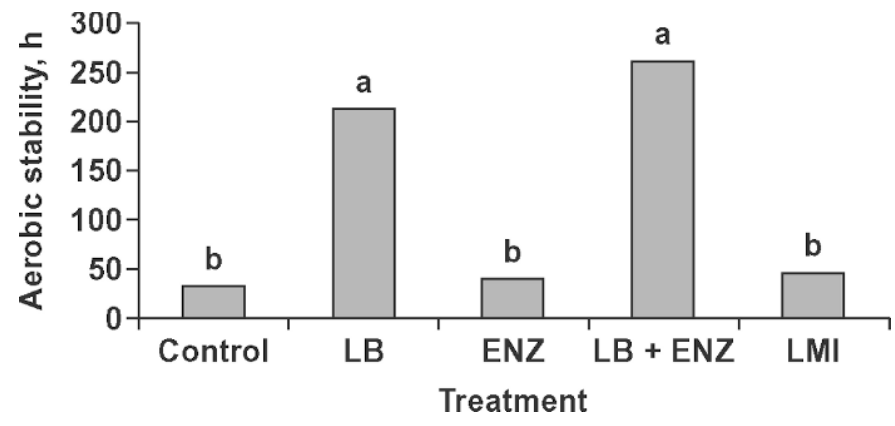

Figure 1. The hours of aerobic stability of untreated whole highmoisture corn (control), corn treated with Lactobacillus buchneri 40788 (LB), corn treated with a mixture of enzymes (ENZ), corn treated with a combination of $\mathrm{LB}+\mathrm{ENZ}$, or corn treated with a liquid mold inhibitor (LMI). SE = 12. Bars with unlike letters differ, $P<$ 0.05 (experiment 1 ).

difficult to predict what organisms would ultimately take advantage of more fermentable substrate. For example, Spoelstra et al. (1992) reported that addition of enzymes to corn silage resulted in a substantial increase in the numbers of yeasts in corn silage and resulted in poor aerobic stability, suggesting that yeasts were able to compete with LAB for usable substrates. Even though addition of L. buchneri 40788 did not reduce the final fungal load in HMC, the aerobic stability (Figure 1) was more than $200 \mathrm{~h}(P<0.05)$ for $\mathrm{LB}$ and LB + ENZ, whereas it was less than $50 \mathrm{~h}$ for the other treatments. Improved aerobic stability in ground HMC treated with L. buchneri 40788 has been previously reported (Taylor and Kung, 2002). The improvements in aerobic stability without a decrease in numbers of yeasts from inoculation with $L$. buchneri 40788 suggests that the higher concentrations of acetic acid in inoculated HMC were sufficient to retard the growth of yeasts when they were exposed to air. The results also showed that the specific enzyme mixture tested and the amount of the specific liquid mold inhibitor used ( $0.1 \%$ of wet weight) had no effects on stability.

Whole HMC is the preferred form of corn that is stored in some silo structures (e.g., many oxygen-limiting silos). It was unknown whether corn in this form had sufficient amounts of available moisture and fermentable substrate to allow for the growth of $L$. buchneri. A current commercial formulation containing $L$. buchneri 40788 has a recommended final application rate of $600,000 \mathrm{cfu} / \mathrm{g}$ of fresh HMC. Therefore, that rate and a lower and higher application rate were evaluated in experiment 2 . The whole HMC used in experiment 2 was similar in composition (Table 1 ) to the corn used in experiment 1 , but notably had a lower concentration of WSC $(0.52$ vs. $1.35 \%)$ than in the first experiment. The results of treating whole HMC with varying levels of $L$. buchneri 40788 after $120 \mathrm{~d}$ of ensiling are shown in Table 3. Regardless of the rate of application, inoculation with L. buchneri 40788 did not affect the DM recovery, $\mathrm{NH}_{3}-\mathrm{N}, \mathrm{ADF}$, or $\mathrm{NDF}$ content of whole HMC. However, there was a linear decrease in DM content $(P<0.01)$ because of inoculation, but this effect was small. Inoculation also resulted in whole HMC with a lower CP content than for untreated HMC $(P=0.01)$. The reason for this finding is unclear, because similar observations were not detected in previous studies (Kleinschmit and Kung, 2006). As expected, inoculation did result in a lower content (average of $0.07 \%)$ of WSC $(P=0.01)$ when compared with untreated corn $(0.16 \%)$. There were trends for inoculated corn to have a lower $\mathrm{pH}$ (average of $4.81, P=$ 0.09 ) and higher lactic acid content (average of $0.17 \%$, $P=0.06)$ when compared with untreated corn $(\mathrm{pH}$ of 4.91 and $0.14 \%$ lactic acid). These findings are in contrast to what has been observed in corn silages treated with $L$. buchneri but might be due to the extent of fermentation being considerably restricted in HMC. As expected, inoculation with L. buchneri 40788 increased $(P<0.01)$ the concentration of acetic acid (average $0.19 \%$ for all dose levels vs. $0.04 \%$ for untreated corn). Greater amounts of lactic and acetic acid and more LAB in inoculated HMC were good indicators that $L$. buchneri 40788 was able to dominate the fermentation process, albeit restricted, even in whole HMC. The concentration of propionic acid was also greater $(P<0.01)$ in inoculated treatments (average of $0.11 \%$ ) than in untreated HMC (undetectable level). Although L. buchneri itself does not produce propionic acid, Krooneman et al. (2002) reported that other organisms are capable of converting a by-product of its metabolism (1,2 propanediol) to propionic acid. The concentrations of ethanol were unaffected by inoculation. Final numbers of LAB were greater $(P<0.01)$ in whole HMC inoculated with $L$. buchneri 40788 (quadratic response, average of $8.75 \mathrm{log} \mathrm{cfu} / \mathrm{g}$ ) than in untreated corn $(7.47 \mathrm{log} \mathrm{cfu} / \mathrm{g})$. The numbers of yeasts (7.29 log cfu/g) and molds (6.05 log cfu/g) after ensiling were high in untreated whole HMC. Inoculated whole HMC had fewer $(P=0.02)$ molds (average of $6.22 \mathrm{log}$ $\mathrm{cfu} / \mathrm{g})$ than did untreated corn (7.29 log cfu/g), and the numbers of yeasts were numerically $(P=0.11)$ lower in inoculated vs. untreated HMC. As a result of the greater concentrations of antifungal components (acetic and propionic) coupled with fewer yeasts and molds, inoculated HMC was more aerobically stable (average of $65 \mathrm{~h}, P<0.01)$ than untreated HMC $(37 \mathrm{~h})$. When L. buchneri 40788 was added to ground HMC, the increased rate of application increased the concentration of acetic acid and improved aerobic stability (Taylor 
Table 3. The effect of varying doses of Lactobacillus buchneri 40788 on the fermentation end-products (DM basis) and microbial populations (wet weight basis) of whole high-moisture corn after $120 \mathrm{~d}$ of storage (experiment 2)

\begin{tabular}{|c|c|c|c|c|c|c|c|c|}
\hline \multirow[b]{2}{*}{ Item } & \multicolumn{4}{|c|}{ Treatment $^{1}$} & \multirow[b]{2}{*}{ SEM } & \multicolumn{3}{|c|}{ Contrast, ${ }^{2} P$} \\
\hline & Control & LB400 & LB600 & LB800 & & 1 & 2 & 3 \\
\hline DM recovery, \% & 96.58 & 96.42 & 96.58 & 96.27 & 0.27 & 0.61 & 0.73 & 0.55 \\
\hline DM, \% & 73.34 & 73.52 & 73.4 & 73.1 & 0.06 & 0.96 & $<0.01$ & 0.24 \\
\hline $\mathrm{CP}, \%$ & 10.13 & 9.71 & 9.84 & 9.83 & 0.10 & 0.01 & 0.43 & 0.63 \\
\hline $\mathrm{NH}_{3}-\mathrm{N}, \%$ & 0.01 & 0.01 & 0.01 & 0.01 & $<0.01$ & 0.17 & 0.67 & 0.88 \\
\hline $\mathrm{ADF}, \%$ & 3.02 & 2.84 & 3.00 & 2.73 & 0.11 & 0.24 & 0.51 & 0.16 \\
\hline NDF, \% & 7.47 & 7.63 & 7.33 & 6.94 & 0.25 & 0.56 & 0.11 & 0.88 \\
\hline Water-soluble carbohydrates, $\%$ & 0.16 & 0.07 & 0.07 & 0.06 & 0.03 & 0.01 & 0.89 & 0.94 \\
\hline $\mathrm{pH}$ & 4.91 & 4.79 & 4.83 & 4.81 & 0.50 & 0.09 & 0.81 & 0.54 \\
\hline Lactic acid, \% & 0.14 & 0.16 & 0.18 & 0.18 & 0.01 & 0.06 & 0.29 & 0.35 \\
\hline Acetic acid, \% & 0.04 & 0.2 & 0.19 & 0.19 & 0.03 & $<0.01$ & 0.91 & 1.00 \\
\hline Propionic acid, \% & 0 & 0.08 & 0.13 & 0.12 & 0.01 & $<0.01$ & 0.07 & 0.10 \\
\hline Ethanol, \% & 1.06 & 1.18 & 1.2 & 1.38 & 0.11 & 0.16 & 0.23 & 0.57 \\
\hline Lactic acid bacteria, log $\mathrm{cfu} / \mathrm{g}$ & 7.47 & 8.73 & 8.82 & 8.7 & 0.06 & $<0.01$ & $<0.01$ & $<0.01$ \\
\hline Molds, log cfu/g & 7.29 & 5.85 & 6.31 & 6.51 & 0.33 & 0.02 & 0.25 & 0.80 \\
\hline Yeasts, log cfu/g & 6.05 & 4.88 & 5.78 & 5.63 & 0.31 & 0.11 & 0.16 & 0.24 \\
\hline Aerobic stability, h & 37 & 65 & 56 & 73 & 10 & $<0.01$ & 0.37 & 0.10 \\
\hline
\end{tabular}

${ }^{1}$ Control $=$ untreated; LB400 $=$ L. buchneri 40788 added to achieve a final application rate of $4 \times 10^{5} \mathrm{cfu} /$ g of wet HMC; LB600 $=$ L. buchneri 40788 added to achieve a final application rate of $6 \times 10^{5} \mathrm{cfu} / \mathrm{g}$ of wet HMC; LB800 $=$ L. buchneri 40788 added to achieve a final application rate of $8 \times 10^{5} \mathrm{cfu} / \mathrm{g}$ of wet HMC.

${ }^{2} 1$ = control vs. $L$. buchneri 40788 addition; $2=$ linear effect of $L$ buchneri 40788 addition; $3=$ quadratic effect of L. buchneri 40788 addition.

and Kung, 2002). Lack of a dose effect in the current experiment (for most measurements) may have been due to the limited amount of available WSC $(0.52 \%)$ in whole HMC. Thus, adding more organisms made little difference because of the lack of fermentable substrate.

\section{CONCLUSIONS}

Treating ground HMC corn with L. buchneri 40788 improved its aerobic stability by increasing the concentration of acetic acid. However, the enzymes, when added alone or with $L$. buchneri, had no effect on the fermentation, chemical composition, or aerobic stability of ground HMC. Addition of a liquid mold inhibitor comprising several antifungal compounds, added at $0.1 \%$ of wet weight, did not improve the aerobic stability of ground HMC. Treating whole HMC with $L$. buchneri 40788 increased the concentrations of acetic and propionic acids, decreased the fungal populations, and improved the aerobic stability of this feed. These studies suggest that addition of $L$. buchneri 40788 has the ability to improve the aerobic stability of ground and whole HMC when they are harvested at the DM used in this study.

\section{REFERENCES}

Britt, D. G., and J. T. Huber. 1975. Preservation and animal performance of high moisture corn treated with ammonia or propionic acid. J. Dairy Sci. 59:668-674.
Dawson, T. R., S. R. Rust, and M. T. Yokoyama. 1998. Improved fermentation and aerobic stability of ensiled high moisture corn with the use of Propionibacterium acidipropionici. J. Dairy Sci. 81:1015-1021.

Hesser, J. M., P. A. Hartman, and R. A. Saul. 1967. Lactobacilli in ensiled high-moisture corn. Appl. Microbiol. 15:49-54.

Hoffman, P. C., and S. M. Ocker. 1997. Quantification of milk yield losses associated with feeding aerobically unstable high moisture corn. J. Dairy Sci. 80(Suppl. 1):234. (Abstr.)

Kendall, C., P. C. Hoffman, and D. K. Combs. 2002. Performance of dairy cattle fed high moisture shelled corn inoculated with Lactobacillus buchneri. J. Dairy Sci. 85(Suppl. 1):385. (Abstr.)

Kleinschmit, D. H., and L. Kung, Jr. 2006. A meta-analysis of the effects of Lactobacillus buchneri on the fermentation and aerobic stability of corn, grass and small grain silages. J. Dairy Sci. 89:4005-4013.

Krooneman, J., F. Faber, A. C. Alderkamp, S. J. H. W. Oude Elferink, F. Driehuis, I. Cleenwerck, J. Swings, J. C. Gottschal, and M. Vancanneyt. 2002. Lactobacillus diolivorans sp. Nov., a 1,2-propanediol-degrading bacterium isolated from aerobically stable maize silage. Int. J. Syst. Evol. Microbiol. 52:639-646.

Kung, L., Jr., and N. K. Ranjit. 2001. The effect of Lactobacillus buchneri and other additives on the fermentation and aerobic stability of barley silage. J. Dairy Sci. 84:1149-1155.

Kung, L., Jr., J. R. Robinson, N. K. Ranjit, J. H. Chen, and C. M. Golt. 2000. Microbial populations, fermentation end products, and aerobic stability of corn silage treated with ammonia or a propionic acid-based preservative. J. Dairy Sci. 83:1479-1486.

Muck, R. E. 1996. A lactic acid bacteria strain to improve aerobic stability of silages. Pages 42-43 in US Dairy Forage Research Center 1996 Research Summaries. US Dairy Forage Research Center, Madison, WI.

Oude Elferink, S. J. W. H., J. Krooneman, J. C. Gottschal, S. F. Spoelstra, F. Faber, and F. Driehuis. 2001. Anaerobic conversion of lactic acid to acetic acid and 1,2-propanediol by Lactobacillus buchneri. Appl. Environ. Microbiol. 67:125-132.

Phillip, L. E., and V. Fellner. 1992. Effects of bacterial inoculation of high moisture ear corn on its aerobic stability, digestion, and utilization for growth by steers. J. Anim. Sci. 70:3178-3187. 
SAS Institute. 1999. SAS User's Guide: Statistics. Version 8.01 Edition. SAS Inst., Inc., Cary, NC.

Sebastian, S., L. E. Phillip, V. Fellner, and E. S. Idziak. 1996. Comparative assessment of bacterial inoculation and propionic acid treatment on aerobic stability and microbial populations of ensiled high-moisture ear corn. J. Anim. Sci. 74:447-456.

Snedecor, G. W., and W. G. Cochran. 1980. Statistical Methods. 6th ed. Iowa State Univ. Press, Ames.

Spoelstra, S. F., P. G. van Wikselaar, and B. Harder. 1992. The effects of ensiling whole crop maize with a multi-enzyme preparation on the chemical composition of the resulting silages. J. Sci. Food Agric. 60:223-228.
Taylor, C. C., and L. Kung, Jr. 2002. The effect of Lactobacillus buchneri 40788 on the fermentation and aerobic stability of high moisture corn in laboratory silos. J. Dairy Sci. 85:1526-1532.

Torriani, S., M. Palummeri, L. Coscia, M. Baetens, and F. Dellaglio. 1992. Detection and characterization of epiphytic lactic acid bacteria on growing plants of maize and lucerne. Ann. Microbiol. Enzymol. 42:49-59.

Wardynski, F. A., S. R. Rust, and M. T. Yokoyama. 1993. Effect of microbial inoculation of high-moisture corn on fermentation characteristics, aerobic stability, and cattle performance. J. Anim. Sci. 71:2246-2252.

Woolford, M. K. 1990. The detrimental effects of air on silage. J. Appl. Bacteriol. 68:101-116. 